\title{
Renewable Energy Deployment and COVID-19 Measures for Sustainable Development
}

\author{
Miraj Ahmed Bhuiyan ${ }^{1}$, Jaehyung An ${ }^{2}$, Alexey Mikhaylov ${ }^{3, *}$, Nikita Moiseev ${ }^{4} \mathbb{C}$ and Mir Sayed Shah Danish ${ }^{5}$ \\ 1 School of Economics, Guangdong University of Finance \& Economics, Guangzhou 510320, China; \\ ahmedbhuiyan@ya.ru \\ 2 College of Business, Hankuk University of Foreign Studies, Seoul 02450, Korea; jaehyung.an@yahoo.com \\ 3 Financial Faculty, Financial University under the Government of the Russian Federation, \\ 124167 Moscow, Russia \\ 4 Department of Mathematical Methods in Economics, Plekhanov Russian University of Economics, \\ 117997 Moscow, Russia; mr.nikitamoiseev@gmail.com \\ 5 Strategic Research Projects Center, University of the Ryukyus, Okinawa 903-0213, Japan; \\ mdanish@lab.u-ryukyu.ac.jp \\ * Correspondence: ayumihajlov@fa.ru; Tel.: +7-901-908-9817
}

check for updates

Citation: Bhuiyan, M.A.; An, J.; Mikhaylov, A.; Moiseev, N.; Danish, M.S.S. Renewable Energy Deployment and COVID-19 Measures for Sustainable Development. Sustainability 2021, 13, 4418. https:// doi.org/10.3390/su13084418

Academic Editor: Antonio Caggiano

Received: 12 March 2021

Accepted: 14 April 2021

Published: 15 April 2021

Publisher's Note: MDPI stays neutral with regard to jurisdictional claims in published maps and institutional affiliations.

Copyright: (c) 2021 by the authors. Licensee MDPI, Basel, Switzerland. This article is an open access article distributed under the terms and conditions of the Creative Commons Attribution (CC BY) license (https:/ / creativecommons.org/licenses/by/ $4.0 /)$.

\begin{abstract}
The main goal of this study is to evaluate the impact of restrictive measures introduced in connection with COVID-19 on consumption in renewable energy markets. The study will be based on the hypothesis that similar changes in human behavior can be expected in the future with the further spread of COVID-19 and/or the introduction of additional quarantine measures around the world. The analysis also yielded additional results. The strongest reductions in energy generation occurred in countries with a high percentage (more than $80 \%$ ) of urban population (Brazil, USA, the United Kingdom and Germany). This study uses two models created with the Keras Long Short-Term Memory (Keras LSTM) Model, and 76 and 10 parameters are involved. This article suggests that various restrictive strategies reduced the sustainable demand for renewable energy and led to a drop in economic growth, slowing the growth of COVID-19 infections in 2020. It is unknown to what extent the observed slowdown in the spread from March 2020 to September 2020 due to the policy's impact and not the interaction between the virus and the external environment. All renewable energy producers decreased the volume of renewable energy market supply in 2020 (except China).
\end{abstract}

Keywords: sustainable growth; pandemic situation; framing effect; renewable energy; COVID-19; risk averse

\section{Introduction}

Coronavirus disease 2019 (COVID-19) is a contagious disease caused by severe acute respiratory syndrome coronavirus 2 (SARS-CoV-2). This article studies the renewable energy supply and COVID-19 measures based on official statistics of the World Health Organization (WHO) and British Petroleum (BP) on the energy and virus spread around the world.

This article quantifies the impact of various strategies adopted worldwide against the spread of COVID-19, such as business closures and face masks. Policies directly affect the spread of COVID-19 (for example, the requirement of a mask) and indirectly affect its spread by changing people's behavior (for example, the order to stay at home). The author's model provides a framework for identifying the causality of the increase or decrease in COVID-19 cases and deaths due to three factors: (1) the political effect, (2) the framing effect through behavior and (3) the rational behavioral effect.

The novelty of this work is the effect of COVID-19 measures on renewable energy generation between 2020 and 2025. This paper's importance is in the analysis of COVID-19 effects on consumption in renewable energy markets. The main goal of this study is to evaluate the impact of restrictive measures introduced in connection with COVID-19 on 
consumption and, accordingly, on renewable generation. There are many studies related to renewable energy deployment [1-5]. Nonetheless, little research exists on the implementation of COVID-19 measures for sustainable development. Most of the available literature concerns only with the influence that renewable energy might have on sustainability without adequately addressing the economic impacts [3]. Few references are dealing with this impact, such as comparing the influence of COVID-19 [4,5] or proposing potential trade-offs among economic objectives considering different measures types [3].

The methodology depends on the theoretical innovation approach of LSTM models that emphasize the relationship between structural changes in different segments of the financial market [2]. Experts note that the relationship between market segments is often unstable. Any change in energy prices caused by economic growth fluctuations complicates the choice of an optimal sustainable transit strategy [2]. This paper includes empirical research that is reliable when selecting articles with high accuracy. Google Scholar and SCOPUS databases were used, a one-year period was included in the analysis (1 January 2020-31 December 2020), and keywords (COVID-19; renewable energy) were used for selecting articles, where a total of 15,700 were obtained. The final list of works includes 12 selected papers.

This paper contributes to the literature in that it fills the theoretical gap in the approach for the analysis of COVID-19 effects on global sustainable growth. The empirical analysis can become the first step for understanding the renewable energy deployment and COVID19 measures for sustainable development.

Further research is needed to better understand the direct impacts that COVID-19 has on measures for sustainable development, particularly sustainability. The main goal of this study is to evaluate the impact of restrictive measures introduced in connection with COVID-19 on consumption and, accordingly, on renewable generation.

\section{Literature Review}

The COVID-19 pandemic began with the first discoveries of pneumonia of unknown origin by locals at the end of December 2019 in Wuhan. China informed the World Health Organization (WHO) about an unknown pneumonia disease outbreak on 31 December 2019. The WHO announced that the outbreak had become a pandemic on 11 March 2020. Afterward, many countries began to impose quarantine regimes or restrict citizens' movement. The decision to introduce restrictions against the COVID-19 pandemic is a classic example of making decisions in the face of uncertainty [1,2].

The impact of COVID-19 and its figures on the population is evident, but it should be emphasized that many people will not suffer from mental disorders. However, a significant percentage will experience intense reactions, mainly in the form of fear of contagion due to the quarantine's extension, the loss of loved ones, or because of the economic crisis. Authorities depend on decision-making problems and, correspondingly, have time-varying risk preferences, which indicates that persons make decisions about anti-COVID-19 measures based on the potential value of deaths instead of on the end result $[3,4]$.

This paper fills the gap in the body of knowledge about two effects. The presence of the COVID-19 impact on renewable energy production is proved in highly developed countries (USA, UK and Germany) and the classic COVID-19 effect on renewable energy production in emerging countries (Brazil, China, Russia) [5,6].

The government has a higher probability of avoiding risk when faced with a positive frame and searching for risk when faced with a negative frame. From this moment onward, the framing effect has become a well-documented bias in various studies. Since then, many papers have demonstrated the framing effect's sustainability in different contexts. The goal is to compare the significance of subjects' characteristics on the framing effect's impact on anti-COVID-19 decisions between February and March of 2020. On the other hand, previous coronaviruses' experiences guiding health personnel of the first line is a 
subgroup of special risk, especially when the current phase of containment of the pandemic ends [5-7].

Regarding the possible impact on the general population in China, a survey of 1210 people revealed that out of the $53.8 \%$ who rated the psychological impact of the situation, $16.5 \%$ reported depressive symptoms, $28.8 \%$ reported moderate to severe anxiety symptoms and $8.1 \%$ reported stress levels between moderate and severe [8-18]. It is also indicated that the framing effect includes numerous effects on sustainability, and various perceptual and cognitive processes can be used [9-11].

The renewable energy deployment was discussed in many previous papers from many points of view [9-13]:

Efficient feed-in-tariff policies for renewable energy technologies;

Understanding the dynamics and policy for renewable energy diffusion in Colombia;

Cost-efficient demand-pull policies for multipurpose technologies: the case of stationary electricity storage;

Integrated benefit-cost analysis of China's optimal adaptation and targeted mitigation;

Local demand-pull policy and energy innovation: evidence from the solar photovoltaic market in China.

There are many factors influencing the public intention to use renewable energy technologies in South Korea, such as the effects of the Fukushima nuclear accident. Authorities need to avoid ignorance of unspecified information [12,13]. It supports the hypotheses about (1) the political effect, (2) the framing effect through behavior and (3) the rational behavioral effect.

The various restrictive policies are expected to reduce the sustainable demand for renewable energy and led to a drop in economic growth, slowing the growth of COVID-19 infections in $2020[14,15]$. This article also assesses to what extent the observed slowdown in the spread from March 2020 to September 2020 is due to the impact of politics and the extent to which the peculiarities of the interaction of the virus itself and the external environment. This question is crucial for assessing the effectiveness of restrictive policies in the future.

The behavior theory is the theoretical background of the study. Most empirical studies are on the relationship between energy dynamics and economic growth. For example, Kanas found a significant positive effect of the stock market on exchange rate changes in all countries except Germany [14]. It described the effect of the flow of volatility between the renewable energy market's economic growth in the COVID-19 pandemic period [9].

Most empirical studies using LSTM models emphasize the relationship between structural changes in different segments of the financial market [15]. Experts note that the relationship between market segments is often unstable. Any change in energy prices caused by economic growth fluctuations complicates the choice of an optimal sustainable transit strategy [16]. In addition, the principle of returning to the mean (mean reversal), applicable over a long-term time interval, can lead to errors when choosing the time for a transaction with various financial assets [17].

Renewable energy sources have contributed to the development of a sustainable global economy. The expansion of carbon dioxide emissions is an integral part of a country's economic growth. In the economic literature, the links between economic growth and pollution are analyzed $[5,18-20]$.

\section{Materials and Methods}

Many articles are devoted to various aspects of the use of renewable energy sources. They emphasize the lack of financial sustainability as a key factor that hinders the development of the industry. The financial sector during COVID-19 plays an important role in the development of energy.

The authors analyze a large amount of information taken from the World Health Organization (WHO) and British Petroleum (BP), including daily new COVID-19 cases and renewable energy generation volume. The assessment is carried out using a set 
of indicators that characterize the level of maturity of the economy in accordance with international standards.

Any intervention must be based on an exhaustive evaluation of the possible risk factors that may perpetuate the problem and the patient's previous sustainable development state. It was discovered that all countries use two main decision-making strategies: one reflects the data decision-making process, and the other demonstrates the process based on experience. Results show that older people will opt for the data-based strategy with less probability compared to younger adults. Still, only those who use a data-based strategy demonstrate the framing effect's presence, which suggests that the framing effect may be more associated with decision-making [16,17].

This study uses two models created with the Keras Long Short-Term Memory model (Keras LSTM) (Figures 1 and 2). The first model forecasts renewable power generation and uses 76 parameters. The second LSTM model estimates new COVID-19 cases across countries. It involves 10 parameters, the data for which are publicly available [18-24]. In the process of model validation, the weight coefficients are evaluated, which do not depend on the absolute value of the variables. Variables with a higher total value are weightier. The architecture of the constructed algorithm is not limited to a single intermediate layer, as in earlier studies [24,25]. The optimal number of nodes in the intermediate layer that allows the network to get the best performance is equal to the logarithm of the number of two samples used to evaluate the network itself.
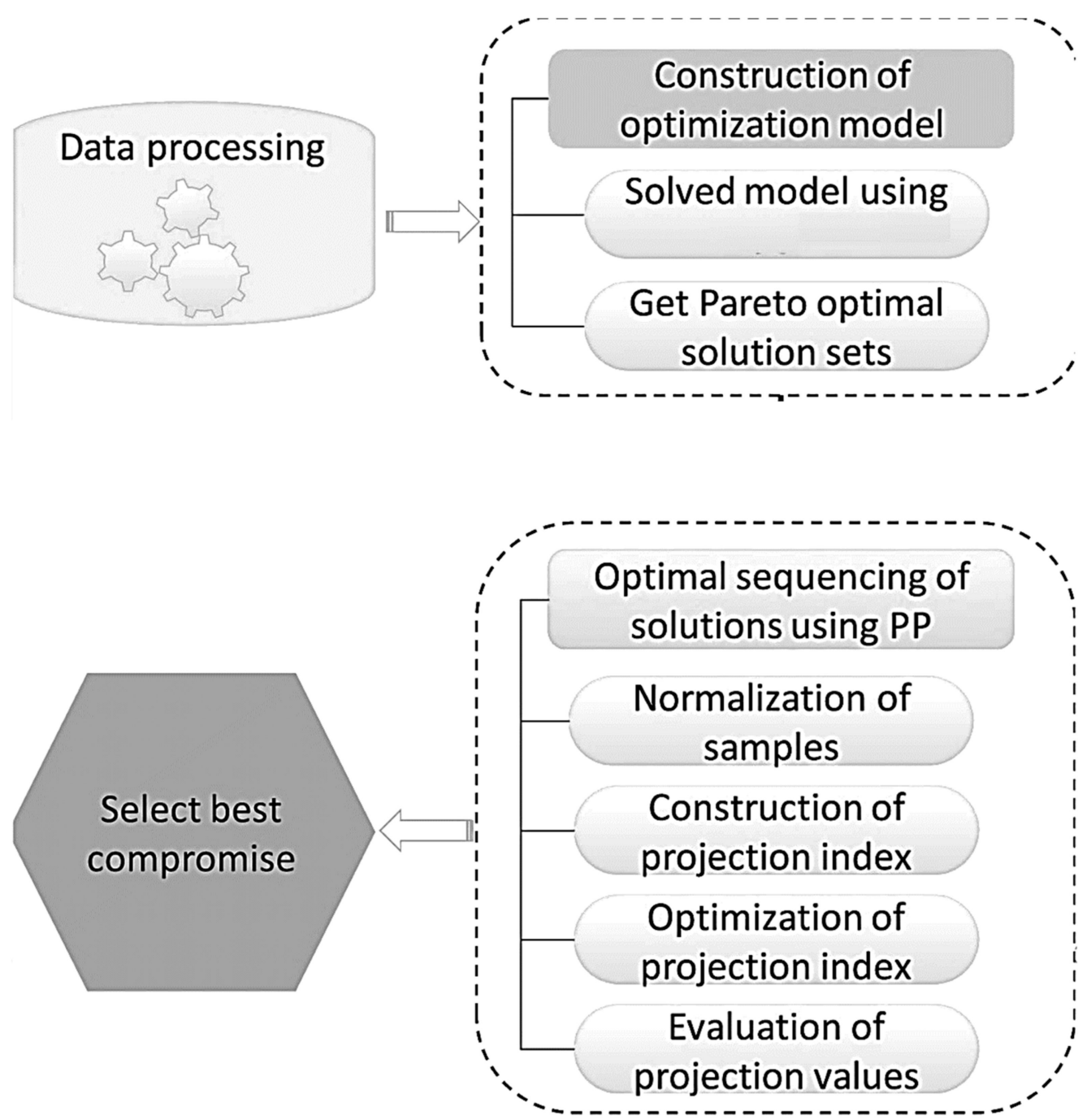

Figure 1. Conceptual framework of the analysis conducted in this study. 


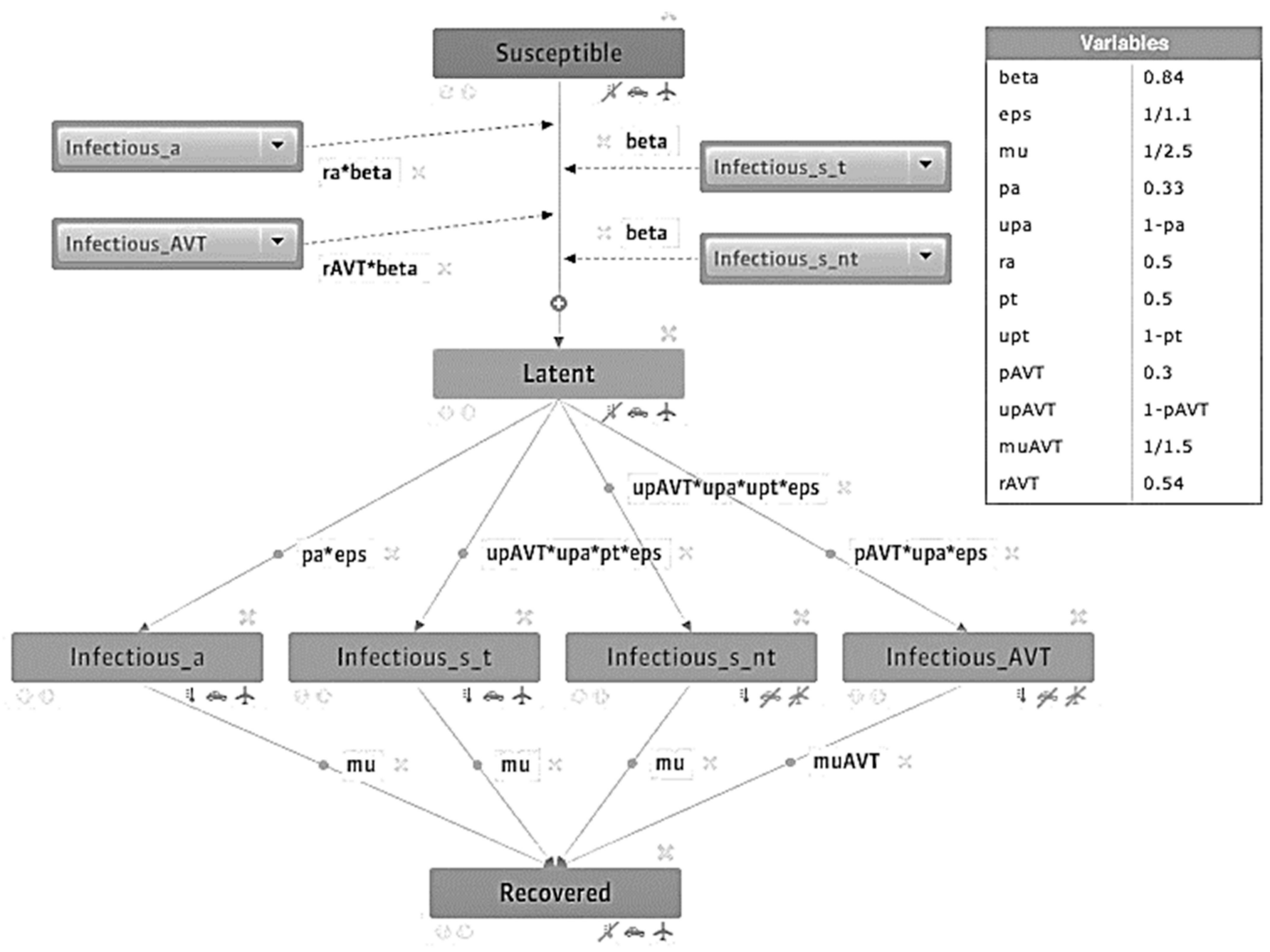

Figure 2. Schema of the model.

The main predictive model used to estimate the parameters of renewable power generation, as well as forecast the spread of COVID-19, consists of two LSTM layers, where the first has 256 neurons and the second has 64. The LSTM itself consists of state blocks that receive input data at regular time intervals. At each time step, the input vector is fed into the LSTM, and the output is calculated according to:

$$
h_{t}=f_{w}\left(h_{t-1}, x_{t}\right)
$$

where $\mathrm{x}_{t}$ is the input vector, $h_{t}$ и $h_{t-1}$ are state vectors at time $t$ and $(t-1)$ and $f_{w}$ is a nonlinear activation function, where $w$ represents different weight parameters.

In this case, the nonlinear OLS (nonlinear least squares (NLS or NLLS)) is most relevant. In many cases, an analytical solution can be obtained. To solve the minimization problem, it is required to find the stationary points of the RSS function, differentiating it by unknown parameters $b$, equating the derivatives to zero and solving the resulting system of equations. For analytical purposes, the last representation of this formula is useful (in the system of equations when divided by $n$, arithmetic averages appear instead of sums). If the data are centered in the regression model, then in this representation, the first matrix has the meaning of a sample covariance matrix of factors, and the second is a vector of covariance of factors with a dependent variable [26-32].

For the LSTM expansion function, for SNNs to work, they need two things: a custom weight initialization method and the activation function, a scaled exponential linear unit (SELU). It is used on the first layer [33-37]. 
A smaller number of adults were biased and felt they were in an unfavorable position, with a likely probability of making sustainable growth decisions [21-29].

It is noteworthy that the ability to compute influence decisions in attributive frames is becoming more evident, but only a few studies have researched computing skills' effect as an influencing factor on renewable-energy-related behavior [30-32]. However, several papers have not reported observing this effect on sustainability [33-35].

However, most studies can examine only a few influential factors because the more variables that they interact with, the more participants and questionnaires are required in these studies [36-39].

Kahneman's perspective theory has specifically the possible outcome that is interpreted and encoded by people as either "gain" or "loss." In fact, actual problems are commonly more complex than those developed in experiments. There are few studies of the effect in Asia, especially regarding healthcare. The low number of studies about this topic in Asia is explained by financial, administrative and other restrictions. To summarize, it should be noted that papers on the framing effect's application to medical decisions in Asia are insufficient [40-42].

The method is based on ordering by the following formula for the next effects: informational delays and physical delays. The formula includes:

1. Time of information and physical delays are defined by $t$;

2. Behavior is implemented, taking into account policies, information and confusions in $t$;

2. Results are implemented on $t+\ell$, taking into account policy, behavior, information and confusion.

$$
\begin{aligned}
Y_{i, t+l}(b, p, t) & =\alpha \mathrm{b}+\pi \mathrm{p}+u \mathrm{t}+\delta_{Y} \mathrm{~W}_{i t}+\varepsilon_{i t}^{y} \\
B_{i t}(p, t) & =\beta \mathrm{p}+\gamma \mathrm{t}+\delta_{\beta} \mathrm{W}_{i t}+\varepsilon_{i t}^{b}
\end{aligned}
$$

where is a set of functional relationships with stochastic shocks, decomposed into the observed part $\delta_{Y} \mathrm{~W}_{i t}$ and the unobservable part $\varepsilon$. The conditions $\varepsilon_{i t}^{y}$ and $\varepsilon_{i t}^{b}$ are centered stochastic shocks that obey the orthogonality constraints set out below. This study's data were daily cumulative cases of COVID-19 infection rates in 210 countries (and dependent territories) from the spread's beginning (February-March) to 11 April 2020. This period is optimal for the evaluation because some countries' measures began to soften after this date.

These data were obtained from a reliable source: the World Health Organization [43]. Many different countries adopted large-scale counteraction measures during this period, and these data were used as a basis to predict the pandemic's spread. The most appropriate model was used to predict detectable cases and for potential mortality rates in various time periods.

Many different countries adopted large-scale counteraction measures during this period, and these data were used as a basis to predict the pandemic's spread. The most appropriate model was used to predict detectable cases and for potential mortality rates in various time periods.

These data were used to revise the Oxford University model's accuracy (Oxford University model, http:/ / epidemicforecasting.org/ (accessed on 15 April 2021)) on the daily spread of COVID-19, which was used by most countries that made decisions regarding the introduction of antivirus measures [44,45].

\section{Results}

The application MATLAB was also used to model data on the total number of daily diagnosed cases of COVID-19 in 2020. The COVID-19 pandemic shows us the wrong decisions that even the most developed countries make. However, they will probably need more time, and they will suffer larger losses due to the COVID-19 framing effect. The independent variable is time $t$, measured in days. There are two sets of dependent variables. 
Potentially infected COVID-19 people:

$$
\frac{d S}{d t}=-b s(t) I(t)
$$

The COVID-19 framing effect in the subject's choice of behavior depending on the frame of choice's option's presentation can manifest itself in the form of reserved preferences or a shift in preferences [46,47]. To further the study on the possible effects of framing, it built a comparison table for the University of Oxford model for choosing a risky option (introducing restrictive state measures) and a risk-free negative option (no restrictions) (Table 1).

Table 1. COVID-19 dependent variables (significance codes: $p<0.01, p<0.05$ ).

\begin{tabular}{ccccccccc}
\hline Main Effects & $\mathbf{R}$ & $\mathbf{R}_{\mathbf{0}}$ & $\boldsymbol{\beta}$ & $\boldsymbol{\gamma}$ & $\mathbf{N}$ & $\mathbf{C}$ & $\mathbf{S}$ & $\mathbf{R M S E}$ \\
\hline Frame (China) & 0.65 & 1.94 & 0.259 & 0.152 & $1,460,000$ & $1,139,010$ & 321,266 & 14,660 \\
\hline Frame (USA) & 0.85 & 1.16 & 1.631 & 1.406 & 312,163 & 82,251 & 229,912 & 1532 \\
\hline Frame (Italy) & 0.53 & 2.12 & 0.201 & 0.095 & 275,355 & 228,105 & 47,250 & 9807 \\
\hline Frame (Spain) & 0.43 & 2.17 & 0.317 & 0.146 & 257,397 & 215,621 & 41,776 & 3048 \\
\hline Frame (Germany) & 0.43 & 2.21 & 0.297 & 0.134 & 190,632 & 161,524 & 29,107 & 2021 \\
\hline Frame (UK) & 0.69 & 1.89 & 0.3 & 0.159 & 248,411 & 189,725 & 58,686 & 1588 \\
\hline Frame (Turkey) & 0.69 & 1.77 & 0.344 & 0.194 & 191,967 & 138,767 & 53,200 & 2361 \\
\hline Frame (Iran) & 0.69 & 1.52 & 0.334 & 0.22 & 165,212 & 98,358 & 66,854 & 1456 \\
\hline Frame (Sweden) & 0.94 & 1.72 & 0.204 & 0.119 & 44,534 & 31,210 & 13,325 & 485 \\
\hline Frame (South Korea) & 0.16 & 3.11 & 0.51 & 0.164 & 9253 & 8767 & 487 \\
\hline Frame (1 group) & 0.75 & 1.55 & 0.945 & 0.779 & $886,216.5$ & 82,251 & 275,589 & 8096 \\
\hline Frame (2 group) & 0.57666666 & 1.94666666 & 0.29883333 & 0.158 & $221,495.6667$ & $172,016.666$ & $49,478.8333$ & 3380.16666 \\
\hline Frame (3 group) & 0.55 & 2.415 & 0.357 & 0.1415 & $26,893.5$ & $19,988.5$ & 6906 & 768.5 \\
\hline
\end{tabular}

Source: authors' calculations. Note: population groups are: more than 300 million-China, USA; 300-50 million-Italy, Spain, UK, Germany, Turkey, Iran; less than 50 million—Sweden, South Korea. $\mathrm{R}$-number of people infected by one person $\beta / \gamma(1-\mathrm{C} / \mathrm{N}))$; $\mathrm{R}_{0} \_$basic reproduction $(\beta / \gamma) ; \beta$-average contact frequency (1/day); $\gamma$-average removal frequency (1/day); $\mathrm{N}$-initial size of the susceptible population; $\mathrm{C}$ - net recovered persons S-Net number of susceptible persons left.

The government measures the effect on the number of people infected by one person and the average contact frequency (1/day). In high-level-population countries, the average contact frequency (1/day) is significantly stronger (0.779) than in middle- $(0.158)$ and low-level-population countries (0.1415). Therefore, the hypothesis on the presence of the COVID-19 effect on renewable energy production is proved in highly developed countries (USA, UK and Germany) and the classic COVID-19 effect on renewable energy production in emerging countries (Brazil, Russia). Prognoses were made according to economic growth and renewable energy production during the COVID-19 pandemic. (Figures 3-8, Appendix A). 


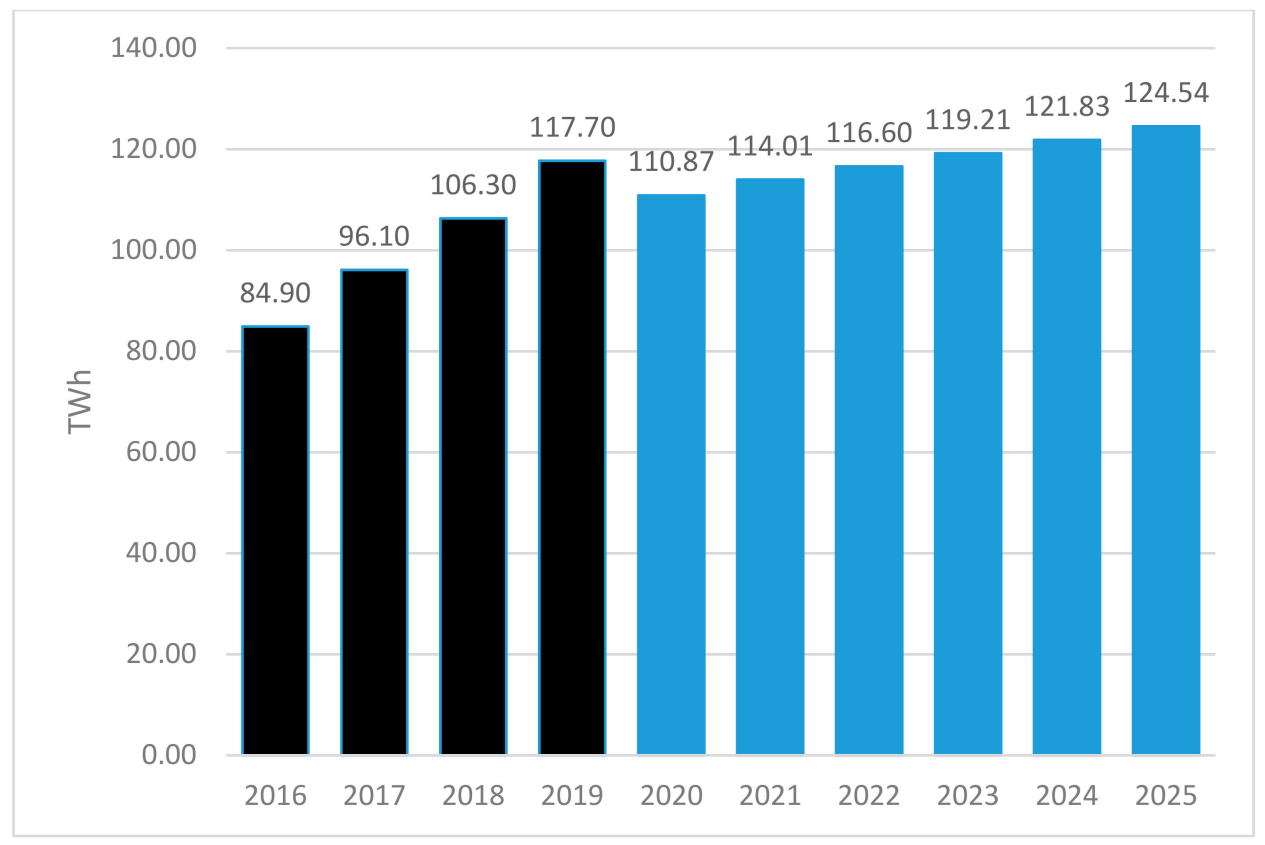

Figure 3. Renewable energy production data (2016-2019) and forecast (2020-2025) in Brazil, TWh. Source: authors' calculations [29].

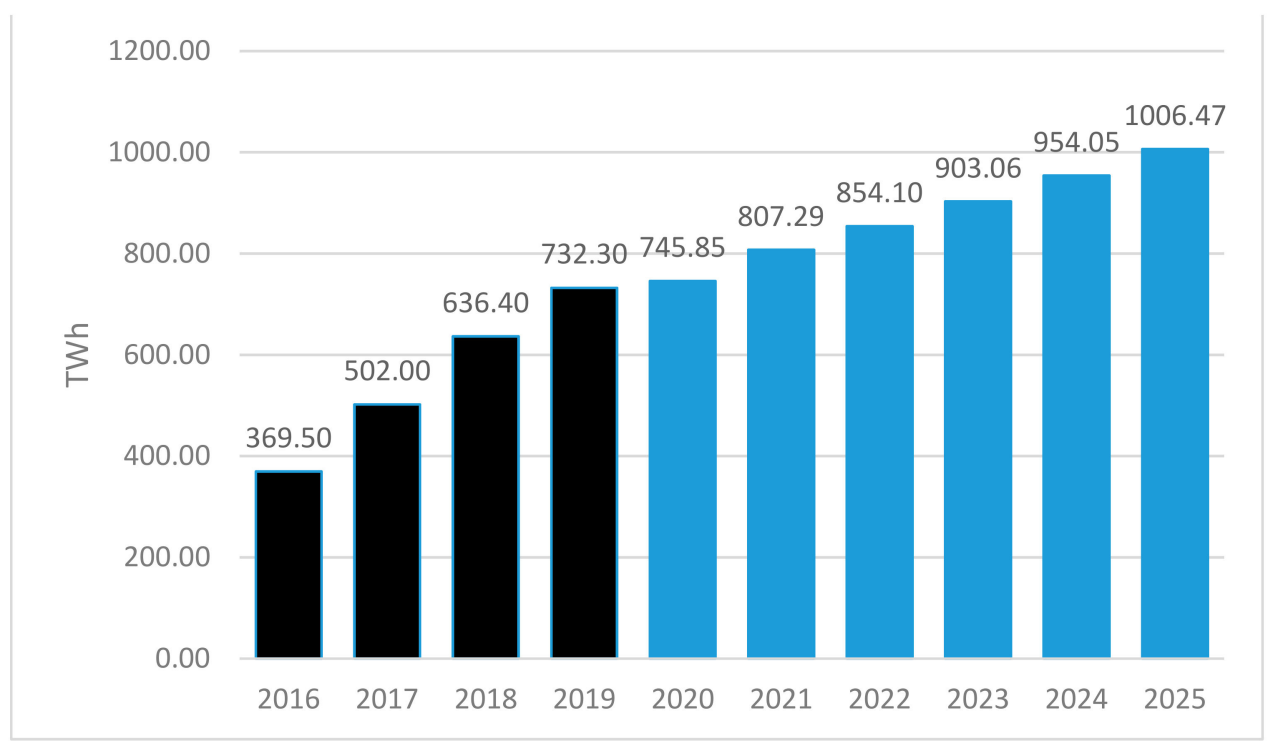

Figure 4. Renewable energy production data (2016-2019) and forecast (2020-2025) in China, TWh. Source: authors' calculations [29]. 


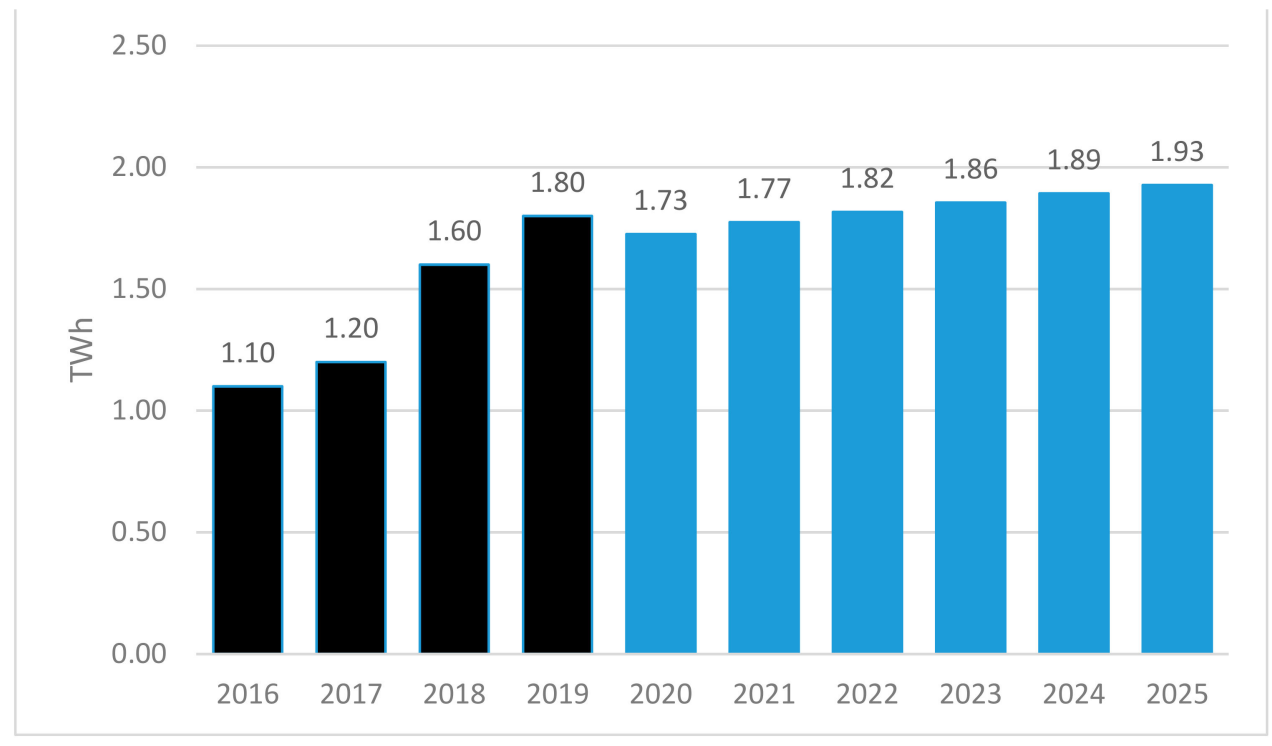

Figure 5. Renewable energy production data (2016-2019) and forecast (2020-2025) in Russia, TWh. Source: authors' calculations [29].

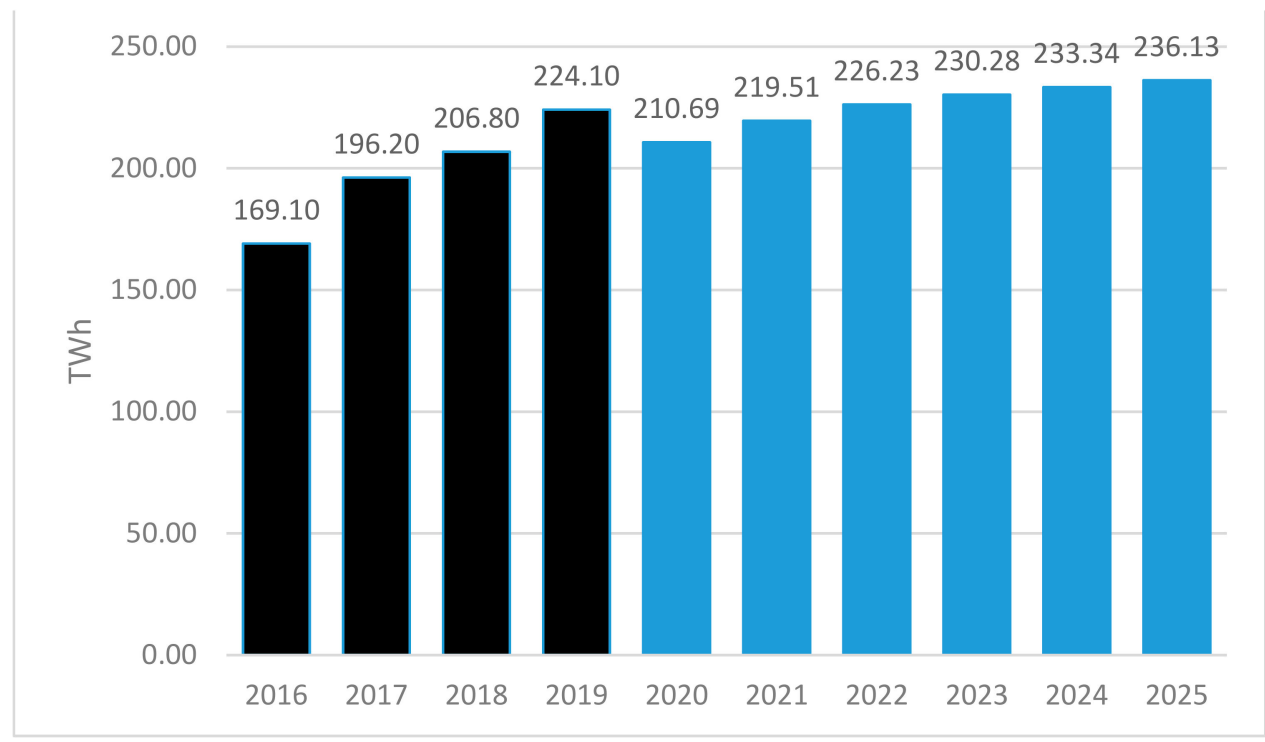

Figure 6. Renewable energy production data (2016-2019) and forecast (2020-2025) in Germany, TWh. Source: authors' calculations [29]. 


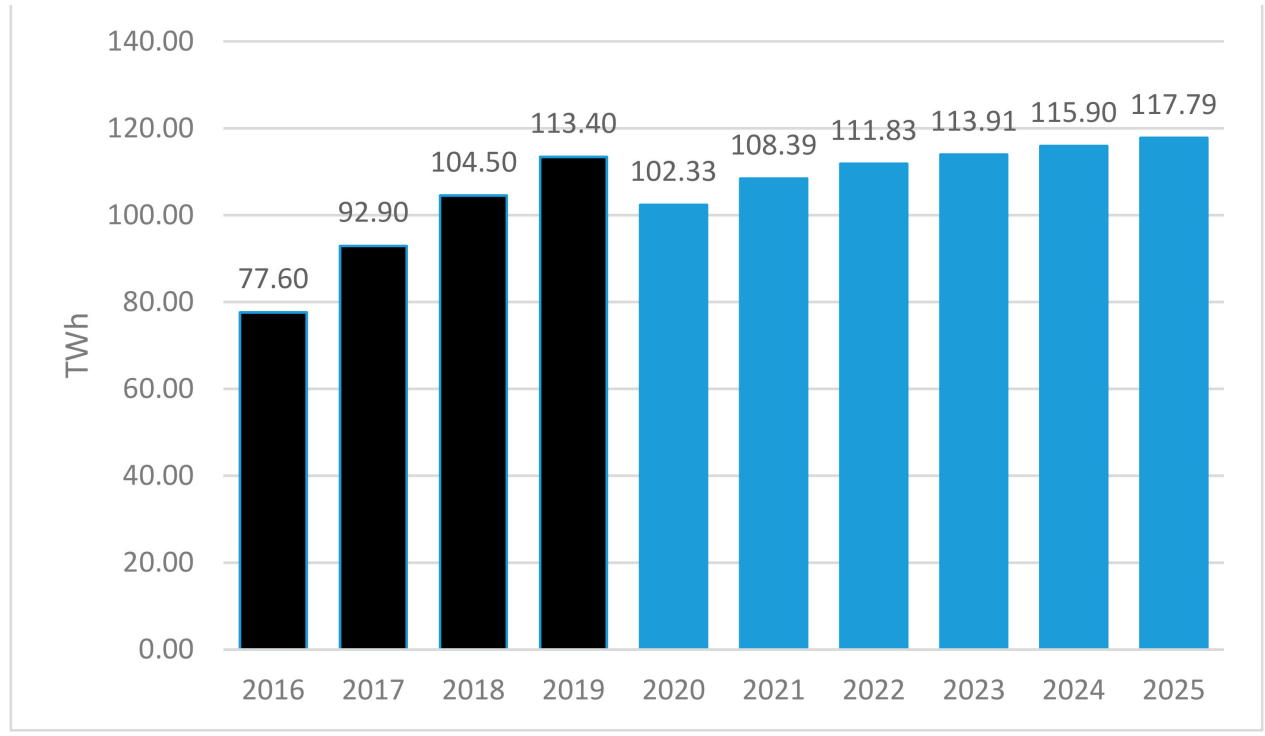

Figure 7. Renewable energy production data (2016-2019) and forecast (2020-2025) in the United Kingdom, TWh. Source: authors' calculations [29].

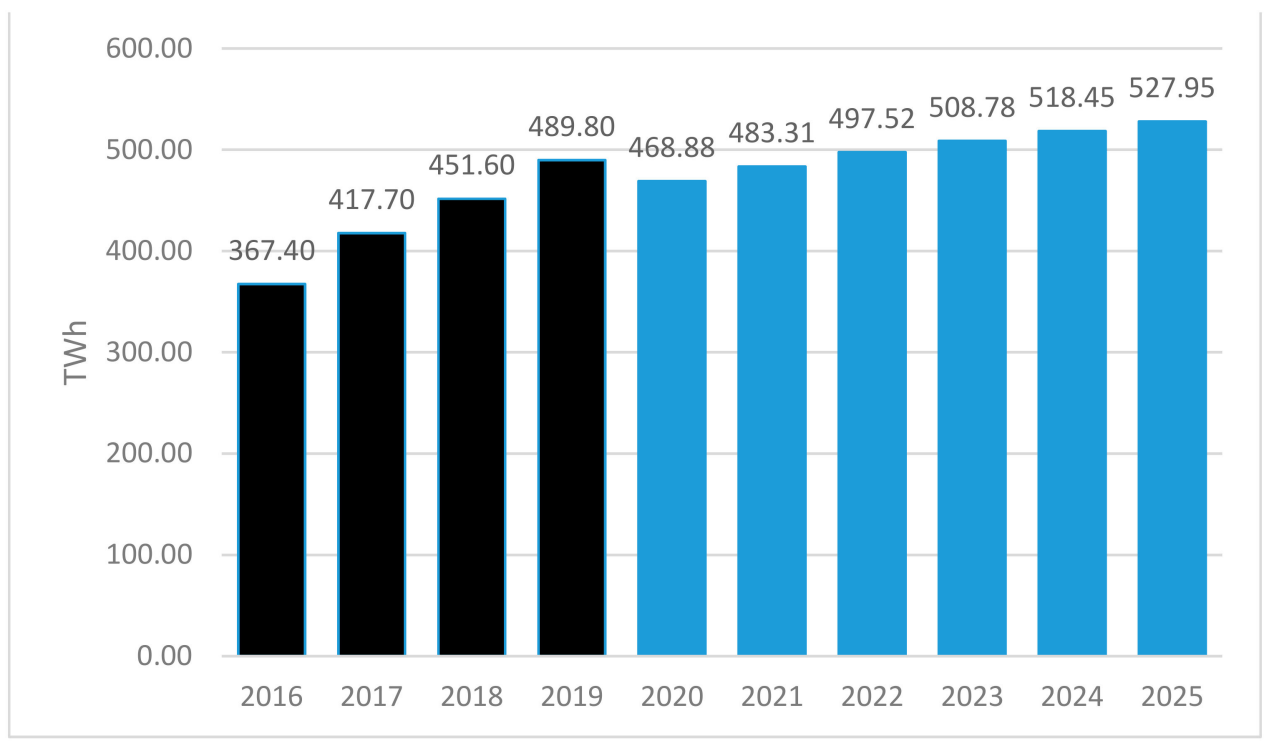

Figure 8. Renewable energy production data (2016-2019) and forecast (2020-2025) in the United States, TWh. Source: authors' calculations [29].

The analysis includes the following factors: the country's population (more than 300 million people, 300-500 million people, less than 50 million people). Note that the model's accuracy (RMSE) was evaluated on the same historical data, but they are described from two different points of view: risk-free negative results and risky positive results. There is a strong presence of the COVID-19 framing effect in all experimental conditions, as can be concluded from Table 1.

Structural validity measures the degree of adequacy of the relationship of the measured structure [41]. In this study, structural validity was assessed using confirmatory factor analysis (CFA). One-dimensionality was investigated by the CFA method on a polychoric correlation matrix using the least squares method (LSM) and variance adjustment (VA). The comparative price index (CPI), the Tucker-Lewis Index (TLI), the root-mean-square approximation error (RMSAE), and the standardized root-mean-square remainder (SRMR) allow for an improved model fit (Table 2). 
Table 2. T-scores.

\begin{tabular}{ccc}
\hline Factor & LSM & VA \\
\hline Policy & 33.4 & 9.1 \\
Behavior & 35.5 & 22.1 \\
Information & 26.0 & 15.8 \\
Confusion & 20.9 & 14.0 \\
PRWE Total & 46.9 & 27.1 \\
MHQ-ADL & 57.4 & 34.8 \\
\hline
\end{tabular}

Government bodies are more vulnerable to risk when choosing a positive outcome than selecting a negative outcome. This effect is enhanced when the decision is postponed for high-level-population countries (more than 300 million) than for low-level-population countries (less than 50 million).

As a result, the simulation confirmed that there is a difference in the frequencies of pattern selection concerning the country's population. The risky decision was made in the USA (Figure 4) earlier than other countries' actions in the corresponding time of choice [48-53].

This model has a very high explanation, although typical regression assumptions apply to Keras models. The very high accuracies reported in this paper might result from spurious effects and that the result might not be relevant for applied researchers. One way to alleviate this problem would be to redo the analysis after differentiating the variables associated with renewable energy generation as the dependent variable (Appendix A).

COVID-19 has become a global epidemic, leading to serious complications that further reduce the quality of life and its expectancy, contributing to an increase in patients' mortality rate. In this regard, the assessment of the COVID-19 framing effect on renewable energy is a priority task.

\section{Discussion}

At the start of the outbreak of COVID-19, the absence of proper economic planning afterward caused these to be implemented disorganized and ineffectively, also compromising access to available social and health resources. Considering recent events, the same mistakes were made, mainly in the framing effect in renewable energy [45-54].

This paper's results prove the novelty of this work: a practical approach concerning the COVID-19 measures and recommendations that enable sustainable development in the time of COVID-19 measures.

The analysis also yielded additional results. The strongest reductions in energy generation occurred in countries with a high percentage (more than $80 \%$ ) of urban population (Brazil, USA, the United Kingdom and Germany). This study used two models created with the Keras LSTM model. The first model forecasts power generation and uses 76 parameters. The second LSTM model forecasts new COVID-19 cases across countries, in which 10 parameters are involved [55-58].

This article suggests that various restrictive strategies reduced sustainable demand for renewable energy and led to a drop in economic growth, slowing the growth of COVID-19 infections in 2020. It is unknown to what extent the observed slowdown in the spread from March 2020 to September 2020 due to the policy's impact and not the interaction between the virus and the external environment. All renewable energy producers decreased the volume of renewable energy supply in 2020 (except China) [59-65]. The results expand the literature and show that various COVID-19 restrictive strategies led to a reduction in sustainable demand for renewable energy [66-68].

\section{Conclusions}

In conclusion, the restrictive measures imposed by the COVID 19 pandemic have led to a reduction in energy consumption, regardless of its source of production, not only that produced from renewable resources [15-17]. This paper proves that the various restrictive 
strategies led to a reduction in sustainable demand for renewable energy and a drop in economic growth, slowing the growth of COVID-19 infections in 2020.

The government measures the effect on the number of people infected by one person and the average contact frequency (1/day). In high-level-population countries, the average contact frequency (1/day) is significantly stronger (0.779) than in middle- $(0.158)$ and low-level-population countries (0.1415). Therefore, the hypothesis on the presence of the COVID-19 effect on renewable energy production is proved in highly developed countries (USA, UK and Germany) and the classic COVID-19 effect on renewable energy production in emerging countries (Brazil, Russia). All renewable energy producers (except China) decreased the volume of renewable energy supply in 2020.

This paper proved the idea about the framing effect in renewable energy and sustainability. In future research, the question about the COVID-19 framing effect in different countries will be addressed. The results for the theory and method development showed that various restrictive strategies led to a reduction in sustainable demand for renewable energy and a drop in economic growth, slowing COVID-19 infections in 2020.

The importance of the results is high because future studies may determine the extent to which the observed slowdown is spread is due to the impact of policies rather than the interaction of the virus itself and the external environment.

This paper has limitations. For the forecast of global energy consumption in pandemic conditions, it is first necessary to know the evolution of economic growth, which, unfortunately, is impossible to make exactly at this time.

Author Contributions: Conceptualization, M.A.B., J.A. and A.M.; software, M.A.B., J.A., A.M. and N.M.; validation, M.A.B., J.A., A.M., N.M. and M.S.S.D.; writing-original draft: A.M; writingreview and editing: A.M. All authors have read and agreed to the published version of the manuscript.

Funding: The second author was supported by the Hankuk University of Foreign Studies Research Fund.

Institutional Review Board Statement: Not applicable.

Informed Consent Statement: Not applicable.

Data Availability Statement: Data sharing not applicable.

Conflicts of Interest: The authors declare no conflict of interest.

\section{Appendix A}

Table A1. Renewable energy production and forecast summary.

\begin{tabular}{|c|c|c|c|c|c|c|c|c|c|c|c|c|c|}
\hline Indicator & RMSE & MAPE & DAR & 2016 & 2017 & 2018 & 2019 & 2020 & 2021 & 2022 & 2023 & 2024 & 2025 \\
\hline Brazil. \% & - & - & - & -3.28 & 1.32 & 1.32 & 1.14 & -5.80 & 2.83 & 2.27 & 2.24 & 2.21 & 2.22 \\
\hline Brazil. TWh & 12.26 & 5.52 & 0.31 & 84.90 & 96.10 & 106.30 & 117.70 & 110.87 & 114.01 & 116.60 & 119.21 & 121.83 & 124.54 \\
\hline China. \% & - & - & - & 6.85 & 6.95 & 6.75 & 6.11 & 1.85 & 8.24 & 5.80 & 5.73 & 5.65 & 5.49 \\
\hline China. TWh & 15.23 & 12.55 & 0.22 & 369.50 & 502.00 & 636.40 & 732.30 & 745.85 & 807.29 & 854.10 & 903.06 & 954.05 & 1006.47 \\
\hline Russia. \% & - & - & - & 0.19 & 1.83 & 2.54 & 1.34 & -4.12 & 2.82 & 2.35 & 2.15 & 2.05 & 1.80 \\
\hline Russia. TWh & 19.26 & 17.62 & 0.13 & 1.10 & 1.20 & 1.60 & 1.80 & 1.73 & 1.77 & 1.82 & 1.86 & 1.89 & 1.93 \\
\hline Germany. \% & - & - & - & 2.23 & 2.60 & 1.27 & 0.56 & -5.98 & 4.18 & 3.06 & 1.79 & 1.33 & 1.20 \\
\hline Germany. TWh & 11.18 & 12.73 & 0.69 & 169.10 & 196.20 & 206.80 & 224.10 & 210.69 & 219.51 & 226.23 & 230.28 & 233.34 & 236.13 \\
\hline United Kingdom. \% & - & - & - & 1.92 & 1.89 & 1.34 & 1.46 & -9.76 & 5.92 & 3.17 & 1.86 & 1.75 & 1.63 \\
\hline United Kingdom. TWh & 18.21 & 16.35 & 0.15 & 77.60 & 92.90 & 104.50 & 113.40 & 102.33 & 108.39 & 111.83 & 113.91 & 115.90 & 117.79 \\
\hline United States. \% & - & - & - & 1.71 & 2.33 & 3.00 & 2.16 & -4.27 & 3.08 & 2.94 & 2.26 & 1.90 & 1.83 \\
\hline United States. TWh & 12.322 & 10.745 & 0.215 & 367.40 & 417.70 & 451.60 & 489.80 & 468.88 & 483.31 & 497.52 & 508.78 & 518.45 & 527.95 \\
\hline
\end{tabular}




\section{References}

1. Mylenka, T. Impact of COVID-19 on the Global Energy Sector. Available online: https://www.pv-magazine.com/2020/04/24 /impact-of-COVID-19-on-the-global-energy-sector/ (accessed on 24 April 2020).

2. Newman, P. The rise and rise of renewable cities. Renew. Energy Environ. Sustain. 2017, 2, 10. [CrossRef]

3. Nyangarika, A.; Mikhaylov, A.; Richter, U. Influence Oil Price towards Economic Indicators in Russia. Int. J. Energy Econ. Policy 2019, 9, 123-130. [CrossRef]

4. Nyangarika, A.; Mikhaylov, A.; Richter, U. Oil Price Factors: Forecasting on the Base of Modified Auto-regressive Integrated Moving Average Model. Int. J. Energy Econ. Policy 2019, 9, 149-160.

5. Nyangarika, A.; Mikhaylov, A.; Tang, B.-J. Correlation of Oil Prices and Gross Domestic Product in Oil Producing Countries. Int. J. Energy Econ. Policy 2019, 8, 42-48.

6. Ozili, P.K. Impact of digital finance on financial inclusion and stability. Borsa Istanb. Rev. 2018, 18, 329-340. [CrossRef]

7. Ozimek, A.; The Future of RemoteWork. SSRN Electron. J. 2020. Available online: https://papers.ssrn.com/sol3/papers.cfm? abstract_id=3638597 (accessed on 12 February 2021).

8. Park, E.; Ohm, J.Y. Factors influencing the public intention to use renewable energy technologies in South Korea: Effects of the Fukushima nuclear accident. Energy Policy 2014, 65, 198-211. [CrossRef]

9. Rana, A.; Perera, P.; Ruparathna, R.; Karunathilake, H.; Hewage, K.; Alam, M.S.; Sadiq, R. Occupant-based energy upgrades selection for Canadian residential buildings based on field energy data and calibrated simulations. J. Clean. Prod. 2020, 271, 122430. [CrossRef]

10. Raza, N.; Akbar, M.Q.; Soofi, A.A.; Akbar, S. Study of Smart Grid Communication Network Architectures and Technologies. J. Comput. Commun. 2019, 7, 19-29. [CrossRef]

11. Renewable Energy News \& Research Renewables Now. Available online: https://renewablesnow.com/ (accessed on 10 April 2020).

12. Renewables Achieve Clean Energy Record as COVID-19 Hits Demand-Renewable Energy World. Available online: https: / / www.renewableenergyworld.com/2020/04/06/renewablesachieve-clean-energy-record-as-covid-19-hits-demand/ (accessed on 11 April 2020).

13. Santiago, I.; Moreno-Munoz, A.; Quintero-Jiménez, P.; Garcia-Torres, F.; Gonzalez-Redondo, M. Electricity demand during pandemic times: The case of the COVID-19 in Spain. Energy Policy 2021, 148, 111964. [CrossRef]

14. Schmidt, T.S.; Steffen, B.; Egli, F.; Pahle, M.; Tietjen, O.; Edenhofer, O. Adverse effects of rising interest rates on sustainable energy transitions. Nat. Sustain. 2019, 2, 879-885. [CrossRef]

15. Singhal, D.; Swarup, K. Electricity price forecasting using artificial neural networks. Int. J. Electr. Power Energy Syst. 2011, 33, 550-555. [CrossRef]

16. Steffen, B.; Egli, F.; Pahle, M.; Schmidt, T.S. Navigating the Clean Energy Transition in the COVID-19 Crisis. Joule 2020, 4, 1137-1141. [CrossRef] [PubMed]

17. Tsao, Y.-C.; Thanh, V.-V. A multi-objective fuzzy robust optimization approach for designing sustainable and reliable power systems under uncertainty. Appl. Soft Comput. 2020, 92, 106317. [CrossRef]

18. Wanas, N.; El-Saban, M.; Ashour, H.; Ammar, W. Automatic scoring of online discussion posts. In Proceedings of the 2nd ACM workshop on Video Summarization-TVS '08; ACM: New York, NY, USA, 2008; pp. 19-26.

19. Wang, B.; Liu, Y.; Qian, J.; Parker, S.K. Achieving Effective Remote Working during the COVID-19 Pandemic: AWor Design Perspective. Appl. Psychol. 2021, 70, 16-59. [CrossRef]

20. Why the Future ofWork Might Be 'Hybrid'. Available online: https://www.bbc.com/worklife/article/20200824-why-thefutureof-work-might-be-hybrid (accessed on 15 November 2020).

21. World Health Organization: Pandemic preparedness. Available online: http://www.who.int/csr/disease/influenza/pandemic/ en/ (accessed on 15 April 2021).

22. Yusup, Y.; Ramli, N.; Kayode, J.; Yin, C.; Hisham, S.; Isa, H.M.; Ahmad, M. Atmospheric Carbon Dioxide and Electricity Production Due to Lockdown. Sustainability 2020, 12, 9397. [CrossRef]

23. Alizamir, S.; De Véricourt, F.; Sun, P. Efficient Feed-In-Tariff Policies for Renewable Energy Technologies. Oper. Res. 2016, 64, 52-66. [CrossRef]

24. Arias-Gaviria, J.; Carvajal-Quintero, S.X.; Arango-Aramburo, S. Understanding dynamics and policy for renewable energy diffusion in Colombia. Renew. Energy 2019, 139, 1111-1119. [CrossRef]

25. Bahar, H.; The Coronavirus Pandemic Could Derail Renewable Energy's Progress. Governments Can Help. Available online: https:/ / www.iea.org/commentaries/the-coronavirus-pandemic-could-derail-renewable-energy-s-progress-governmentscan-help (accessed on 4 April 2020).

26. Battke, B.; Schmidt, T.S. Cost-efficient demand-pull policies for multi-purpose technologies-the case of stationary electricity storage. Appl. Energy 2015, 155, 334-348. [CrossRef]

27. Bhuiyan, T.H.; Medal, H.R.; Harun, S. A stochastic programming model with endogenous and exogenous uncertainty for reliable network design under ran- dom disruption. Eur. J. Oper. Res. 2020, 285, 670-694. [CrossRef]

28. Big Oil's Interest in Renewable Energy Investments Expected to Waver, Report Says-The Globe and Mail. Available online: https: / / www.theglobeandmail.com/business/article-big-oilsinterest-in-renewable-energy-investments-expected-to-waver/ (accessed on 10 April 2020). 
29. Statistical Review of World Energy 2020. Available online: https://www.bp.com/content/dam/bp/business-sites/en/global/ corporate/pdfs/energy-economics/statistical-review/bp-stats-review-2020-full-report.pdf (accessed on 15 April 2021).

30. Duan, H.; Zhang, G.; Wang, S.; Fan, Y. Integrated benefit-cost analysis of China's optimal adaptation and targeted mitiga-tion. Ecol. Econ. 2019, 160, 76-86. [CrossRef]

31. European Commission Clean Energy for All Europeans. Available online: https://ec.europa.eu/energy/en/topics/ energystrategy-and-energy-union/clean-energy-all-europeans (accessed on 1 July 2018).

32. European Commission. A Framework Strategy for a Resilient Energy Union with a Forward-Looking Climate Change Policy; 25.2.2015 $\operatorname{COM}(2015) 80$ Final; European Commission: Brussels, Belgium, 2015.

33. Fact Sheet-Jobs in Renewable Energy, Energy Efficiency, and Resilience (2019) I White Papers I EESI. Available online: https: / / www.eesi.org/papers / view / fact-sheet-jobs-inrenewable-energy-energy-efficiency-and-resilience-2019 (accessed on 10 April 2020).

34. Fernández-Agüera, J.; Domínguez-Amarillo, S.; Sendra, J.J.; Suárez, R. An approach to modelling envelope airtightness in multi-family social housing in Mediterranean Europe based on the situation in Spain. Energy Build. 2016, 128, 236-253. [CrossRef]

35. Gangolells, M.; Casals, M.; Forcada, N.; Macarulla, M.; Cuerva, E. Energy mapping of existing building stock in Spain. J. Clean. Prod. 2016, 112, 3895-3904. [CrossRef]

36. Gareta, R.; Romeo, L.M.; Gil, A. Forecasting of electricity prices with neural networks. Energy Convers. Manag. 2006, 47, 1770-1778. [CrossRef]

37. Gholizadeh, H.; Fazlollahtabar, H.; Khalilzadeh, M. A robust fuzzy stochastic programming for sustainable procurement and logistics under hybrid uncertainty using big data. J. Clean. Prod. 2020, 258, 120640. [CrossRef]

38. Gilani, M.A.; Kazemi, A.; Ghasemi, M. Distribution system resilience enhance- ment by microgrid formation considering distributed energy resources. Energy 2020, 191, 116442. [CrossRef]

39. Gobierno, P. Del Normativa Básica de Edificación. Condiciones Térmicas de los Edificios. NBE-CT-79 1979. Available online: https: / / www.boe.es/buscar/doc.php?id=BOE-A-1979-24866 (accessed on 30 November 2020).

40. Golušin, M.; Dodi 'c, S.; Popov, S. Chapter 2-Energy and Sustainable Development. In Sustainable Energy Management; Golušin, M., Dodi'c, S., Popov, S., Eds.; Academic Press Inc.: Cambridge, MA, USA, 2013; pp. 7-57. ISBN 9780124159785.

41. Goodarzian, F.; Hosseini-Nasab, H.; Muñuzuri, J.; Fakhrzad, M.-B. A multi-ob- jective pharmaceutical supply chain net-work based on a robust fuzzy model: A comparison of meta-heuristics. Appl. Soft Comput. 2020, 92, 106331. [CrossRef]

42. Guillén-Lambea, S.; Rodríguez-Soria, B.; Marín, J.M. Air infiltrations and energy demand for residential low energy buildings in warm climates. Renew. Sustain. Energy Rev. 2019, 116, 109469. [CrossRef]

43. Guillén-Lambea, S.; Rodríguez-Soria, B.; Marín, J.M. Comfort settings and energy demand for residential nZEB in warm cli-mates. Appl. Energy 2017, 202, 471-486. [CrossRef]

44. Guillén-Lambea, S.; Rodríguez-Soria, B.; Marín, J.M. Control strategies for Energy Recovery Ventilators in the South of Eu-rope for residential nZEB-Quantitative analysis of the air conditioning demand. Energy Build. 2017, 146, 271-282. [CrossRef]

45. Guillén-Lambea, S.; Rodríguez-Soria, B.; Marín, J.M. Review of European ventilation strategies to meet the cooling and heat-ing demands of nearly zero energy buildings (nZEB)/Passivhaus. Comparison with the USA. Renew. Sustain. Energy Rev. 2016, 62, 561-574. [CrossRef]

46. Hosseini, S.E.; Wahid, M.A. Hydrogen production from renewable and sustainable energy resources: Promising green energy carrier for clean development. Renew. Sustain. Energy Rev. 2016, 57, 850-866. [CrossRef]

47. Hosseini, S.E. An outlook on the global development of renewable and sustainable energy at the time of COVID-19. Energy Res. Soc. Sci. 2020, 68, 101633. [CrossRef] [PubMed]

48. Hu, S.; Souza, G.C.; Ferguson, M.E.; Wang, W. Capacity investment in renewable energy technology with supply intermit-tency: Data granularity matters! Manuf. Serv. Oper. Manag. 2015, 17, 480-494. [CrossRef]

49. Ikram, M.; Zhang, Q.; Sroufe, R.; Shah, S.Z.A. Towards a sustainable environ- ment: The nexus between ISO 14001, re-newable energy consumption, access to electricity, agriculture and $\mathrm{CO}_{2}$ emissions in SAARC countries. Sustain. Prod. Consum. 2020, 22, 218-230. [CrossRef]

50. Instituto para la Diversificación y Ahorro de la Energía. Manual de Fundamentos Técnicos de Calificación Energética de Edi-ficios Existentes CE3 X; IDAE: Madrid, Spain, 2012.

51. ISO 7730:2005 Ergonomics of the thermal environment-Analytical determination and interpretation of thermal comfort using calculation of the PMV and PPD indices and local thermal comfort criteria. Management 2005, 3, 605-615.

52. Ji, L.; Zhang, B.; Huang, G.; Wang, P. A novel multi-stage fuzzy stochastic pro- gramming for electricity system structure optimization and planning with energy-water nexus- a case study of Tianjin, China. Energy 2020, 190, 116418. [CrossRef]

53. Kavlak, G.; McNerney, J.; Trancik, J.E. Evaluating the causes of cost reduction in photovoltaic modules. Energy Policy 2018, 123, 700-710. [CrossRef]

54. Kök, A.G.; Shang, K.; Yücel, Ş. Impact of electricity pricing policies on renewable energy investments and carbon emissions. Manag. Sci. 2016, 64, 131-148. [CrossRef]

55. Kosai, S.; Cravioto, J. Resilience of standalone hybrid renewable energy systems: The role of storage capacity. Energy 2020, 196, 117133. [CrossRef]

56. Lam, L.T.; Branstetter, L.; Azevedo, I.M. China's wind industry: Leading in deployment, lagging in innovation. Energy Policy 2017, 106, 588-599. [CrossRef] 
57. Li, L.; Liu, J.; Zhu, L.; Zhang, X.B. How to design a dynamic feed-in tariffs mechanism for renewables-a real options ap-proach. Int. J. Prod. Res. 2019, 9, 1-15.

58. Li, T.; Li, A.; Guo, X. The sustainable development-oriented development and utilization of renewable energy industry-A comprehensive analysis of MCDM methods. Energy 2020, 212, 118694. [CrossRef]

59. Liu, J.; Wang, R.; Sun, Y.; Lin, Y.; Xiao, L. A barrier analysis for the development of distributed energy in China: A case study in Fujian province. Energy Policy 2013, 60, 262-271. [CrossRef]

60. López-Mesa, B.; Monzón-Chavarrías, M.; Espinosa-Fernández, A. Energy Retrofit of Social Housing with Cultural Value in Spain Analysis of Strategies Conserving the Original Image vs. Coordinating Its Modification. Sustainability 2020, 12, 5579. [CrossRef]

61. Magazzino, C.; Mele, M.; Schneider, N. A D2C Algorithm on the Natural Gas Consumption and Economic Growth: Chal-lenges faced by Germany and Japan. Energy 2021, 219, 119586. [CrossRef]

62. Magazzino, C.; Mele, M.; Schneider, N. The relationship between air pollution and COVID-19-related deaths: An application to three French cities. Appl. Energy 2020, 279, 115835. [CrossRef]

63. Magazzino, C.; Mele, M.; Schneider, N.; Sarkodie, S.A. Waste generation, Wealth and GHG emissions from the waste sector: Is Denmark on the path towards Circular Economy? Sci. Total Environ. 2021, 755, 142510. [CrossRef]

64. Majumdar, A.; Shaw, M.; Sinha, S.K. COVID-19 debunks the myth of socially sustainable supply chain: A case of the clothing industry in South Asian countries. Sustain. Prod. Consum. 2020, 24, 150-155. [CrossRef]

65. Mastrucci, A.; Marvuglia, A.; Benetto, E.; Leopold, U. A spatio-temporal life cycle assessment framework for building reno-vation scenarios at the urban scale. Renew. Sustain. Energy Rev. 2020, 126, e109834. [CrossRef]

66. Mele, M.; Magazzino, C. Pollution, economic growth, and COVID-19 deaths in India: A machine learning evidence. Environ. Sci. Pollut. Res. 2021, 28, 2669-2677. [CrossRef]

67. Ministerio de Fomento. Documento Básico HE Ahorro de Energía 2019. Código Técnico Edificación. 2019; pp. 1-129. Available online: https: / / www.codigotecnico.org/DocumentosCTE/AhorroEnergia.html (accessed on 30 November 2020).

68. Monzón-Chavarrías, M.; López-Mesa, B.; Resende, J.; Corvacho, H. The nZEB concept and its requirements for residential buildings renovation in Southern Europe: The case of multi-family buildings from 1961 to 1980 in Portugal and Spain. J. Build. Eng. 2021, 34, 101918. [CrossRef] 